Original Research Paper

\title{
Antimicrobial and Antioxidant Activities of Bacterial Extracts from Marine Bacteria Associated with Sponge Stylotella sp.
}

\author{
${ }^{1}$ Daning Yoghiapiscessa, ${ }^{2}$ Irmanida Batubara and ${ }^{1}$ Aris Tri Wahyudi \\ ${ }^{1}$ Department of Biology, Faculty of Mathematics and Natural Sciences, \\ ${ }^{2}$ Department of Chemistry, Faculty of Mathematics and Natural Sciences, \\ Bogor Agricultural University, Jl. Agatis, Dramaga Campus, Bogor 16680, Indonesia
}

Article history

Received: 20-10-2015

Revised: $11-12-2015$

Accepted: 10-02-2016

Corresponding Author: Aris Tri Wahyudi

Department of Biology, Faculty of Mathematics and Natural

Sciences, Bogor Agricultural

University, Indonesia

Phone/Fax: +62-251-8622833

Email: aristri2011@gmail.com

\begin{abstract}
Sponge-associated bacteria have great potential in developing marine pharmaceutical industry since they are capable of synthesizing numerous bioactive metabolite compounds. This study aimed to isolate, characterize and investigate potential antimicrobial, toxicity and antioxidant of bioactive compounds of bacteria associated with sponge Stylotella sp. A total of 138 bacteria were selected. During screening stage, 45 isolates (32\%) produced a wide spectrum and species specific bioactive compound against microbial test strains (Pseudomonas aeruginosa, Staphylococcus aureus, Bacillus subtilis, Eschericia coli ATCC 8739, Enteropathogenic Escherichia coli (EPEC) and Candida albicans). Crude extract of five selected potential bacteria were extracted using ethyl acetate solvent. They were identified to have a wide spectrum inhibition capability against microbial test strains. The extracts toxicity were examined using the Brine Shrimp Lethality Test (BSLT) method. All extracts showed toxicity of $\mathrm{LC}_{50}$ in the range of $35.89-484.17 \mu \mathrm{g} \mathrm{mL}^{-1}$ against Artemia salina. By using Cupric Reducing Antioxidant Capacity (CUPRAC) radical reduction test revealed all the extracts showed potential antioxidant activites, ranging from 445.33 to $1610.00 \mu \mathrm{mol}$ trolox/g extract. Based on 16S rRNA sequence analysis revealed that isolates STIL 33, STIL 37, STIL 44, STIL 55 and STIL 9 were closely related with Pseudoalteromonas flavipulchra strain NCIMB 2033, Serratia marcescens strain NBRC 102204, Catenococcus thiocycli strain TG 5-3, Vibrio natriegens strain ATCC 14048 and Bacillus subtilis strain JCM 1465, respectively.
\end{abstract}

Keywords: Antimicrobial, Toxicity, Antioxidant, CUPRAC, Marine Bacteria

\section{Introduction}

Sponges are sessile aquatic animal of the phylum Porifera which obtain nutrients through filtering the surrounding water column, allowing them to associate with various microorganisms. It is estimated that more than $50 \%$ sponge tissue are symbiont microorganisms (Taylor et al., 2007). Sponge symbiont microorganisms are known capable of synthesizing numerous bioactive compounds with unique, complex and different structure compared with terrestrial microorganisms. Secondary metabolites of sponge microbes are adaptive and play key roles in their host defense mechanism against pathogens, predators and competitors, in addition to in fouling process and competition for space and food resources. Nowadays, it is known that marine sponges and their associated microorganisms are economically important because they produce the most active bioactive compounds that are potentially useful for human in pharmaceutical industry sector, for instance as antimicrobial, antifungal, antioxidant, anticancer and anti-inflammatory agents (Jeganathan et al., 2013). Bioactive compounds mostly found in sponge symbiont microorganisms are generally derived from alkaloids, terpenes, terpenoids and peptides (Mehbub et al., 2014).

Numerous types of infectious diseases caused by pathogenic bacteria or yeast are one of basic problems in biomedical field that need to be seriously controlled. It 
requires continuous development to obtain various types of new antimicrobial compounds capable of acting as therapeutic agents for infections caused by certain pathogenic microorganisms (Penesyan et al., 2009). The arising problems drive the exploration of antimicrobial compound from microorganisms associated with sponge. These bacteria are widely reported to be highly potential as the producer of antimicrobial bioactive compound (Nazim et al., 2014).

Antioxidant compounds have an important role in improving human health. The compounds can decrease the risk of multiple chronic degenerative diseases, for instance gastrointestinal infection, cancer, Alzheimer, cataract and coronary heart disease. Nowadays, alternatives of natural antioxidant compounds are sought and developed to obtain compound which is specific and has better activity. Sponge symbiont microorganism is one of study objects in finding new antioxidant compounds (Pereira et al., 2015). This is because sponge is symbiotic with various autotrophic microorganisms which perform photosynthesis and exposed to numerous free radical sources such as toxic, waste material and continuous intensity of UV radiation, indicating antioxidant activity of sponge bacteria (Taylor et al., 2007). There are several reports on antioxidant compounds which were successfully isolated from sponge bacteria. Acyl-glycol carotenoid acid which is the red pigment of Rubritalea squalenifasciens associated with sponge Halicondria okadai was reported to be antioxidant against the formation of radical chain (Thomas et al., 2010). Antioxidant activities of bacterial extracts have also been reported from bacteria associated with sponge Jaspis sp. collected from Waigeo island, Raja Ampat Papua, Indonesia (Utami et al., 2014).

In the present study, the research focus was to screen marine bacteria associated with sponge Stylotella sp. collected from Kepulauan Seribu-Indonesia producing bioactive compounds and to determine potential bacterial isolates through the antimicrobial, toxicity and antioxidant activities of the bacterial extracts.

\section{Materials and Methods}

\section{Sponge Sample Collection}

The marine sponge Sylotella sp specimens used in this study were collected from Bira island of Kepulauan Seribu, Indonesia. The sponges were manually obtained from 1.5 to $3.0 \mathrm{~m}$ depth with the help of snorkeling mask. Sponge sampling was randomly carried out in the area prior to direct transfer using plastic bags with seawater to prevent sponge tissues contact with air. The samples were then taken onto laboratory for further analysis.

\section{Isolation of Sponge-Associated Bacteria}

Dilution method was applied for the isolation of sponge-associated bacteria. One gram sponge sample was cleaned using sterile sea water to remove the nonattached bacteria. This material was suspended and homogenized in $9 \mathrm{~mL} 0.85 \% \mathrm{NaCl}(0.85 \mathrm{~g} \mathrm{NaCl}, 100$ $\mathrm{mL}$ distilled water) and mixed by vortexing for $10 \mathrm{~min}$. The serial dilution method was then carried out using $0.85 \% \mathrm{NaCl}$ to obtain concentration ranging from $10^{-1}$ to $10^{-5}$, where $100 \mu \mathrm{L}$ was aseptically drawn using pipette from the last four dilutions and spread onto Petri dish containing Sea Water Complete medium (SWC) $(5 \mathrm{~g}$ bacto peptone, $1 \mathrm{~g}$ yeast extract, $3 \mathrm{~mL}$ glycerol, $750 \mathrm{~mL}$ seawater, $250 \mathrm{~mL}$ distilled water, 15 $\mathrm{g}$ agar), Starch Casein Agar (SCA) (1 g casein, $10 \mathrm{~g}$ soluble starch, $20 \mathrm{~g} \mathrm{NaCl}, \mathrm{K}_{2} \mathrm{HPO} 40.5 \mathrm{~g}, 20 \mathrm{~g}$ agar, 1 L distilled water), Nutrient Agar (NA) (13 g nutrient broth, $1 \mathrm{~L}$ distilled water, $20 \mathrm{~g}$ agar), Zobell Marine Agar (ZMA) (40.25 g zobell medium broth, $1 \mathrm{~L}$ distilled water, $20 \mathrm{~g}$ agar) and Marine Agar (MA) (0.5 $\mathrm{g}$ peptone, $0.1 \mathrm{~g}$ yeast extract, $1 \mathrm{~L}$ sea water, $20 \mathrm{~g}$ agar). After that, all plates were incubated at $27^{\circ} \mathrm{C}$ for $48 \mathrm{~h}$. The growing colonies were selected based on the morphological identification (shape, elevation, margin, surface characteristics and color). Representative of each colonies morphology were serially streak-plated on SWC media until pure cultures were obtained.

\section{Screening of Bacteria Producing Antimicrobial Compounds}

Agar-Overlay method was applied for this test. Media used for preliminary screening were SWC for antibacterial test and Potato Dextrose Agar (PDA) (24 g potato dextrose broth, $1 \mathrm{~L}$ distilled water, $20 \mathrm{~g}$ agar) for anti-yeast test. One $\mathrm{mL}$ of liquid culture of tested microorganisms each of $P$. aeruginosa, $S$. aureus (collection of Biotechnology Laboratory, Bogor Agricultural University), B. subtilis, EPEC (collection of Microbiology Laboratory, Bogor Agricultural University), E. coli ATCC 8739 and C. albicans (collection of Microbiology and Parasitology Laboratory, University of Indonesia-Jakarta), was incubated for $24 \mathrm{~h}$ prior to inoculation in $100 \mathrm{~mL} \mathrm{SWC}$ agar medium (antibacterial test) or PDA (anti-yeast test) at $\pm 48^{\circ} \mathrm{C}$ and pouring into Petri dish (1\% (v/v) of microbial test strains (concentration $1 \times 10^{6} \mathrm{CFU} / \mathrm{mL}$ (Colony-Forming Units per milliliter), $\mathrm{OD}_{620}=0.45$ ). The plates were then allowed to set at room temperature and dried. Each of 138 bacterial isolates was streaked on the surface of agar media that have been seeded with above microbial test strains. Plates were incubated for $24 \mathrm{~h}$ at $37^{\circ} \mathrm{C}$. The antimicrobial compound activity was indicated by clear zone formed around bacterial colonies. 


\section{Hemolytic Test}

The bacterial isolates that produced antimicrobial compound were tested to know the possibility of the bacteria include in pathogene bacteria using hemolytic test. The bacterial isolates were streaked onto blood agar medium and incubated overnight $(24 \mathrm{~h})$ at room temperature. Clear zone formed around the colony indicates the positive to lysis blood cells and proves the isolate to be potential pathogens in human. There was no further testing to such isolates.

\section{Extraction of Bioactive Compounds from Bacteria}

The bacterial isolates were cultured in $1 \mathrm{~L}$ SWC broth medium. The cultures were incubated and shaked at $100 \mathrm{rpm}$ for $72 \mathrm{~h}$ at $27^{\circ} \mathrm{C}$. After incubation, bacteria cultures were mixed with ethyl acetate solvent 1: 0.75 $(\mathrm{v} / \mathrm{v})$ ratio in two replications. This was carried out to minimize the saturation level of the solvent to bind bioactive compounds. Mixed solvent and bacteria cultures were stirred at $250 \mathrm{rpm}$ for $12 \mathrm{~h}$ at room temperature. These mixtures were separated and the ethyl acetate layers were evaporated using rotary evaporator at $40^{\circ} \mathrm{C}$. The extracts were vacuumed and stored below $5^{\circ} \mathrm{C}$ for further test (Muller et al., 2004).

\section{Antimicrobial Activity Test}

Antimicrobial activities of crude extracts were tested using agar diffusion method on paper disc $(6 \mathrm{~mm}$ in diameter). A total of $13 \mu \mathrm{L}$ crude extracts $\left(5 \mathrm{mg} \mathrm{mL}^{-1}\right)$ dissolved in ethyl acetate were dropped on sterilized paper disk prior to drying using hair dryer followed with oven at $37^{\circ} \mathrm{C}$ for $2 \mathrm{~h}$. Each paper disc was put on semisolid agar medium which was already been inoculated by $1 \%(\mathrm{v} / \mathrm{v})$ of test liquid culture $(P$. aeruginosa, S. aureus, B. subtilis, E. coli ATCC 8739, EPEC and C. albicans) in cell concentration of $1 \times 10^{6}$ cell $/ \mathrm{mL}\left(\mathrm{OD}_{620}\right.$ 0.45). Positive control used was $5 \mathrm{mg}$ $\mathrm{mL}^{-1}$ ampicillin while the negative control was ethyl acetate solvent soaked-peper disc. Each palte was then incubated at $37^{\circ} \mathrm{C}$ for $24 \mathrm{~h}$. The clear zone formed around the paper disc indicated activity of the bacterial extract to inhibit microbial growth.

\section{Toxicity Test of Bacterial Extracts}

The toxicity of bioactive compound from bacterial extracts were tested using BSLT method in 50\% lethal concentration $\left(\mathrm{LC}_{50}\right)$. Artemia salina eggs $(0.1 \mathrm{~g})$ were inoculated in $200 \mathrm{~mL}$ sea water. The eggs were hatched for $2 \mathrm{~h}$ using aeration system with $30^{\circ} \mathrm{C}$ light. After hatching, active brine shrimp larvae (nauplii) that were free from their egg shells were collected using pipette. Stock solution of $5000 \mathrm{ppm}$ was prepared by dissolving the crude extract $0.05 \mathrm{~g}$ in 500 $\mu \mathrm{L}$ of Dimethyl Sulfoxide (DMSO) that added to 9.5 $\mathrm{mL}$ of sea water. The bacterial extracts were dissolved in sea water with different concentrations $\left(0 \mu \mathrm{g} \mathrm{mL} \mathrm{m}^{-1}\right.$ as the control, 25, 50, 100, 250, 500 and $1000 \mu \mathrm{g}$ $\mathrm{mL}^{-1}$ ) in triplicate. After that, twenty individual nauplii were introduced to each concentration (Meyer et al., 1982). The number of dead larvae was counted after $24 \mathrm{~h}$ exposure. The amount of mortality and logarithm concentration were presented in a linear regression curve. $\mathrm{LC}_{50}$ is the extract concentration that can kill $50 \%$ A. salina larvae and can be calculated following Probit scale analysis.

Equation 1 Percentage mortality $(\% \mathrm{M})$ formula:

$\%$ Mortality
$=\frac{\sum \text { Nauplii Larvae Mortality }-\Sigma \text { Control Mortality }}{\sum \text { Initial Amount of Nauplii Larvae }} \times 100 \%$

\section{Determination of Antioxidant Activity}

Antioxidant activity of each extract was determined using CUPRAC method. One $\mathrm{mL}$ of crude extract $(500$ $\mu \mathrm{g} \mathrm{mL}-1$ ) in ethanol was added with $1 \mathrm{~mL}$ of $7.5 \times 10^{-3} \mathrm{M}$ Neucoprine, $1 \mathrm{~mL}$ of $10^{-2} \mathrm{M} \mathrm{CuCl}_{2}, 1 \mathrm{~mL}$ of $1 \mathrm{M} \mathrm{NH}_{4} \mathrm{Ac}$ and $0.1 \mathrm{~mL} \mathrm{H}_{2} \mathrm{O}$ prior to incubation for $30 \mathrm{~min}$. Standard curve was made using trolox with 50,75, 100, 150, 200 and $400 \mu \mathrm{M}$ in concentration. The sample absorbance and standard curve were then measured using ELISA reader at $450 \mathrm{~nm}$ wavelength. The Antioxidant capacity of crude extract was measured expressed in $\mu \mathrm{mol}$ trolox/g extract (Apak et al., 2008).

\section{PCR Amplification of $16 S$ rRNA gene and Sequence Analysis}

Amplification of 16S rRNA genes was conducted using PCR using the universal primer for bacterial domain, 63f (5'-CAG GCC TAA CAC ATG CAA GTC-3') and 1387r (5'-GGG CGG WGT GTA CAA GGC-3') (Marchesi et al., 1998) which targeted for conserved region and allowed the amplification of an approximately 1300 -bp fragment. PCR was conducted in 25 cycles with the following conditions, predenaturation at $94^{\circ} \mathrm{C}$ for 2 min, denaturation at $92^{\circ} \mathrm{C}$ for $30 \mathrm{sec}$, annealing at $55^{\circ} \mathrm{C}$ for $30 \mathrm{sec}$, elongation at $72^{\circ} \mathrm{C}$ for $1 \mathrm{~min}$ and final elongation (post PCR) at $72^{\circ} \mathrm{C}$ for $7 \mathrm{~min}$. The PCR products were purified and sequenced. The DNA sequences were analyzed using the BlastN program in National Center for Biotechnology Information (NCBI) GenBank database (http://ncbi.nlm.nih.gov/). The alignment of 16S rRNA genes was carried out using MEGA 5.0 software and the phylogenetic tree was constructed using neighborjoining method with $1000 x$ bootstrap replications. 


\section{Results}

\section{Isolation of Bacteria Associated with Sponge Stylotella sp}

Total data calculation of sponge symbiont bacteria on various media showed that, based on total CFU of the highest dilution (30-300 colonies/dish), the highest number of total bacterial growth belonged to

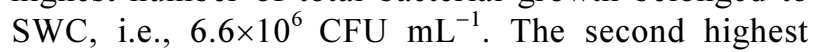

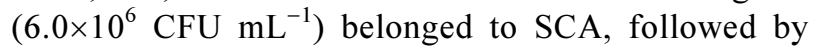

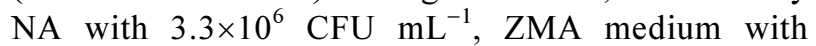
$2.6 \times 10^{6} \mathrm{CFU} \mathrm{mL} \mathrm{mL}^{-1}$ and the lowest, $1.4 \times 10^{6} \mathrm{CFU}$ $\mathrm{mL}^{-1}$, belonged to MA medium. The isolation of sponge Stylotella sp. symbiont bacteria was conducted using five series of dilution for each medium. A total of 138 types of bacteria based on morphological differences were found in the present study. The visual appearances of bacteria associated with sponge Stylotella sp. were mostly round-broken white colonies. There were few colonies which had pink, grey, orange and yellow in color pigmentation (data not shown).

\section{Screening of Bacteria Producing Antimicrobial Compounds}

The analysis result found potential antimicrobial compound activities during secondary screening, i.e., $45(32 \%)$ out of 138 bacterial isolates with capability of inhibiting microbial test strains, or in another word, had antimicrobial compound activities in narrow to wide spectrum activity (Table 1). Twenty nine isolates were narrow spectrum activity and the other, 16 isolates were wide spectrum activity based on their capability of inhibiting more than one microbial test strain. Most of the isolates were capable of inhibiting the growth of $B$. subtilis (21 isolates), followed by inhibitory against EPEC growth (18 isolates), $P$. aeruginosa (17 isolates), $S$. aureus (11 isolates), $E$. coli (9 isolates) and the growth of C. albicans (8 isolates) (Fig. 1).

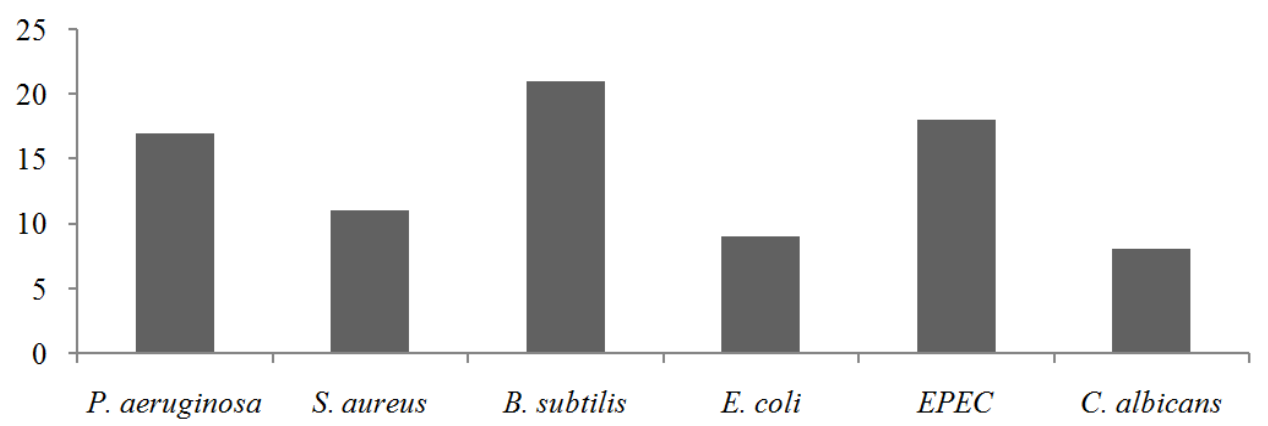

Fig. 1. Number of bacteria isolated from sponge Stylotella sp. which have antimicrobial activity against microbial test strains

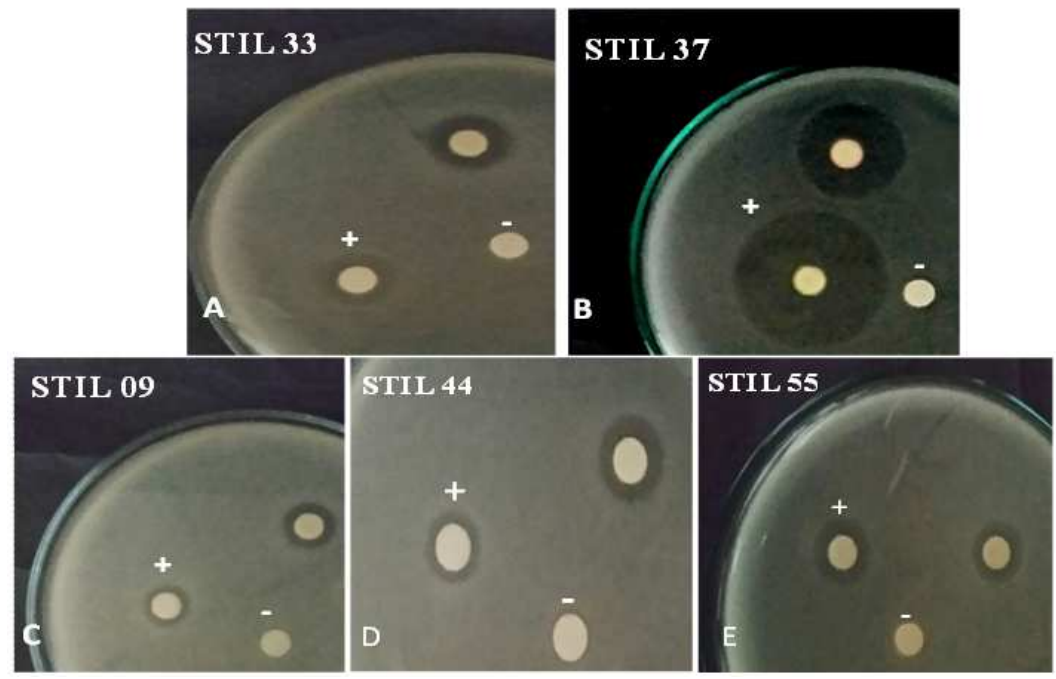

Fig. 2. Clear zones after $24 \mathrm{~h}$ incubation at $37^{\circ} \mathrm{C}$ formed around bacterial extracts. A. STIL 33 against E. coli, B. STIL 37 against $S$. aureus, C. STIL 09 against $C$. albicans, D. STIL 44 against $P$. aeruginosa and E. STIL 55 against EPEC $(+$ control $=$ ampicillin $5 \mathrm{mg} \mathrm{mL}^{-1}$, -control = ethyl acetate) 
Table 1. Antimicrobial activity of sponge-associated bacteria against microbial test strains

\begin{tabular}{|c|c|c|c|c|c|c|c|}
\hline \multirow[b]{2}{*}{ No } & \multirow[b]{2}{*}{ Isolates Code } & \multicolumn{4}{|l|}{ Tested Bacteria } & \multirow[b]{2}{*}{ EPEC } & \multirow{2}{*}{$\begin{array}{l}\text { Tested Yeast } \\
\text { C. albicans }\end{array}$} \\
\hline & & P. aeruginosa & S. aureus & B. subtillis & E. coli & & \\
\hline 1 & STIL 1 & ++ & ++ & - & - & ++ & - \\
\hline 2 & STIL 2 & - & - & + & - & - & - \\
\hline 3 & STIL 4 & + & - & - & - & - & - \\
\hline 4 & STIL 5 & + & - & - & - & - & - \\
\hline 5 & STIL 6 & - & - & - & - & ++ & + \\
\hline 6 & STIL 9 & ++ & +++ & ++ & ++ & + & +++ \\
\hline 7 & STIL 10 & - & '+++ & ++ & +++ & ++ & +++ \\
\hline 8 & STIL 11 & - & - & + & - & - & - \\
\hline 9 & STIL 12 & - & - & ++ & - & - & - \\
\hline 10 & STIL 13 & - & - & ++ & - & ++ & - \\
\hline 11 & STIL 14 & - & - & + & - & - & - \\
\hline 12 & STIL 15 & - & - & ++ & - & - & - \\
\hline 13 & STIL 16 & + & - & - & - & - & - \\
\hline 14 & STIL 17 & - & - & ++ & - & - & - \\
\hline 15 & STIL 18 & ++ & - & - & - & - & - \\
\hline 16 & STIL 19 & ++ & - & - & - & - & - \\
\hline 17 & STIL 20 & - & - & ++ & - & - & - \\
\hline 18 & STIL 21 & + & + & + & + & ++ & + \\
\hline 19 & STIL 22 & - & - & + & - & - & + \\
\hline 20 & STIL 23 & - & - & + & + & - & - \\
\hline 21 & STIL 24 & - & - & + & - & - & - \\
\hline 22 & STIL 25 & - & - & - & - & + & - \\
\hline 23 & STIL 26 & - & + & + & - & - & - \\
\hline 24 & STIL 27 & - & - & - & + & - & - \\
\hline 25 & STIL 28 & + & - & - & - & - & - \\
\hline 26 & STIL 29 & - & - & - & - & ++ & - \\
\hline 27 & STIL 31 & - & - & + & - & - & - \\
\hline 28 & STIL 33 & ++ & + & ++ & ++ & + & ++ \\
\hline 29 & STIL 35 & - & - & - & - & + & - \\
\hline 30 & STIL 37 & ++ & ++ & + & - & ++ & - \\
\hline 31 & STIL 44 & + & + & - & + & + & - \\
\hline 32 & STIL 50 & - & - & - & - & ++ & - \\
\hline 33 & STIL 55 & + & + & - & ++ & - & - \\
\hline 34 & STIL 56 & - & - & - & - & + & - \\
\hline 35 & STIL 57 & ++ & - & - & - & - & - \\
\hline 36 & STIL 64 & - & - & - & ++ & - & + \\
\hline 37 & STIL 66 & - & - & ++ & - & - & - \\
\hline 38 & STIL 71 & - & - & - & - & + & - \\
\hline 39 & STIL 84 & - & - & - & - & + & - \\
\hline 40 & STIL 85 & + & - & - & - & - & - \\
\hline 41 & STIL 89 & - & - & - & - & ++ & - \\
\hline 42 & STIL 93 & - & - & + & - & - & - \\
\hline 43 & STIL 99 & + & + & - & - & +++ & + \\
\hline 44 & STIL 104 & - & - & ++ & - & - & - \\
\hline 45 & STIL 106 & ++ & ++ & - & - & - & - \\
\hline
\end{tabular}

Note: Weak +: 1-5 mm, medium ++: 6-10 mm, strong +++: 11-15 mm, -: no inhibitory activity, +: Positive inhibitory activity

\section{Antimicrobial Activity Test}

Five bacterial extracts with the best antimicrobial activity were extracted using ethyl acetate solvent (STIL 09, STIL 33, STIL 37, STIL 44 and STIL 55). The clear zone formed around paper disk indicated inhibitory activity toward bacterial or yeast test strains (Fig. 2), indicating that the sponge-associated bacteria bacteria produced bioactive compounds. The results showed that all extracts of bacteria associated with sponge were wide spectrum inhibitory activity, i.e., 5 isolates inhibited $P$. aeruginosa, S. aureus and EPEC; 4 isolates inhibited E. coli; and the other 3 isolates inhibited B. subtilis. Antimicrobial activity against yeast (C. albicans) was found in the two extracts, i.e., STIL 09 and STIL 33 (Table 2).

\section{Hemolytic Test Analysis}

The result showed that after $24 \mathrm{~h}$ incubation, 5 out of 45 isolates were positive capable of lysing blood 
cells, indicated by the formation of clear zone around the colonies. The isolates were STIL 12, STIL 18, STIL 19, STIL 20 and STIL 93 (data not shown).

\section{Toxicity of Bacterial Extracts}

The toxicity of bacterial extracts were known through $\mathrm{LC}_{50}$ (Median Lethal Concentration). $\mathrm{LC}_{50}$ is the concentration in which $50 \%$ of larvae A. salina died after being given by extract treatment. Calculation results of the number of larvae A. salina mortality in comparison to the logarithm of the extract concentration were analyzed using Microsoft Excel program, which also gave the regression equations. The regression equations were used to calculate $\mathrm{LC}_{50}$ value. The Bioactive metabolite compound is toxic if it can kill $50 \%$ A. salina larvae less than $1000 \mu \mathrm{g}$ $\mathrm{mL}^{-1}\left(\mathrm{LC}_{50}\right)$ concentration. As shown in Table 3, five extracts from bacteria associated with sponge Stylotella sp (STIL 09, STIL 33, STIL 37, STIL 44 and STIL 55) were toxic against $A$. salina. The highest toxicity was performed by isolate STIL 37 with $\mathrm{LC}_{50}$ of $35.89 \mu \mathrm{g} \mathrm{mL}$, followed by STIL 09 , STIL 33, STIL 44 and STIL 55 with LC $_{50}$ of 69.50 , $484.17,82.79$ and $156.68 \mu \mathrm{g} \mathrm{mL}^{-1}$, respectively.

\section{Antioxidant Activity of Bacterial Extracts}

Antioxidant activity in reducing CUPRAC radical was successfully analyzed in five selected bacterial isolates. The activity was measured in antioxidant capacity unit ( $\mu$ mol trolox/g extract). Results revealed that the extracts from sponge symbiont bacteria had antioxidant capacity in the range of 445.33 to 1610.00 $\mu \mathrm{mol}$ trolox/g extract, with the highest capacity was performed by STIL 33 ethyl acetate crude extract (1610.00 $\mu \mathrm{mol}$ trolox/g extract) (Table 4).

\section{Identification of Bacteria Based on 16S rRNA Gene}

The 16S rRNA genes from five bacterial isolates were successfully amplified by PCR resulting $1300 \mathrm{bp}$ DNA fragments. Those bacterial isolates (STIL 09, STIL 33, STIL 37, STIL 44 and STIL 55) were identified based on 16S rRNA gene sequence analysis. The BlastN results on NCBI Genbank revealed the bacteria associated with sponge Stylotella sp. belonged to the phylum Proteobacteria and phylum Firmicutes. There were 4 out of 5 bacterial isolates belonged to the phylum Proteobacteria, i.e., STIL 33 showed closely related with Pseudoalteromonas flavipulchra NCIMB 2033, while isolate STIL 37 with Serratia marcescens strain NBRC 102204. Other classes were found in isolate STIL 44 showing closely related with Catenococcus thiocycli strain TG 5-3 and isolate STIL 55 closely related with Vibrio natriegens strain ATCC 14048. One isolate STIL 09 referred to the group from phylum Firmicutes, i.e., Bacillus subtilis strain JCM 1465 (Table 5).

Table 2. Antimicrobial activities of five selected bacterial extracts against microbial test strains

\begin{tabular}{|c|c|c|c|c|c|c|c|}
\hline \multirow[b]{2}{*}{ No } & \multirow[b]{2}{*}{ Isolates } & \multicolumn{6}{|c|}{ Microbial Test Strain } \\
\hline & & P. aeruginosa & S. aureus & B. subtillis & E. coli & EPEC & C. albicans \\
\hline 1 & STIL 09 & ++ & ++ & ++ & + & ++ & ++ \\
\hline 2 & STIL 33 & ++ & ++ & ++ & ++ & + & + \\
\hline 3 & STIL 37 & ++ & +++ & ++ & - & +++ & - \\
\hline 4 & STIL 44 & ++ & ++ & - & + & ++ & - \\
\hline 5 & STIL 55 & ++ & ++ & - & + & ++ & - \\
\hline
\end{tabular}

Note: Weak +: 1-5 mm, medium ++: 6-10 mm, strong +++: 11-15 mm, -: No inhibitory activity, +: Positive inhibitory activity.

Table 3. $\mathrm{LC}_{50}$ values of the crude extracts of bacteria associated with sponge Stylotella sp

\begin{tabular}{lr} 
\\
\hline Isolates & $\mathrm{LC}_{50}(\mu \mathrm{g} / \mathrm{mL})$ \\
\hline STIL 09 & 69.50 \\
STIL 33 & 484.17 \\
STIL 37 & 35.89 \\
STIL 44 & 82.79 \\
STIL 55 & 156.68 \\
\hline
\end{tabular}

Table 4. Antioxidant activity of bacterial crude extracts

\begin{tabular}{lc}
\hline Isolates & $\sum$ Antioxidant Capacity $(\mu$ mol trolox/g extract) \\
\hline STIL 09 & 989.67 \\
STIL 33 & 1610.00 \\
STIL 37 & 1202.67 \\
STIL 44 & 787.33 \\
STIL 55 & 445.33 \\
\hline
\end{tabular}


Table 5. Molecular identification of bacteria based on 16S rRNA gene

\begin{tabular}{llll}
\hline Isolates & Closest relative & Maximum identity & Accession No \\
\hline STIL 09 & Bacillus subtilis strain JCM 1465 & $100 \%$ & NR1184861 \\
STIL 33 & Pseudoalteromonas flavipulchra strain NCIMB 2033 & $100 \%$ & NR0251261 \\
STIL 37 & Serratia marcescens strain NBRC 102204 & $100 \%$ & NR1140431 \\
STIL 44 & Catenococcus thiocycli strain TG 5-3 & $100 \%$ & NR1048701 \\
STIL 55 & Vibrio natriegens strain ATCC 14048 & $100 \%$ & NR1178901 \\
\hline
\end{tabular}

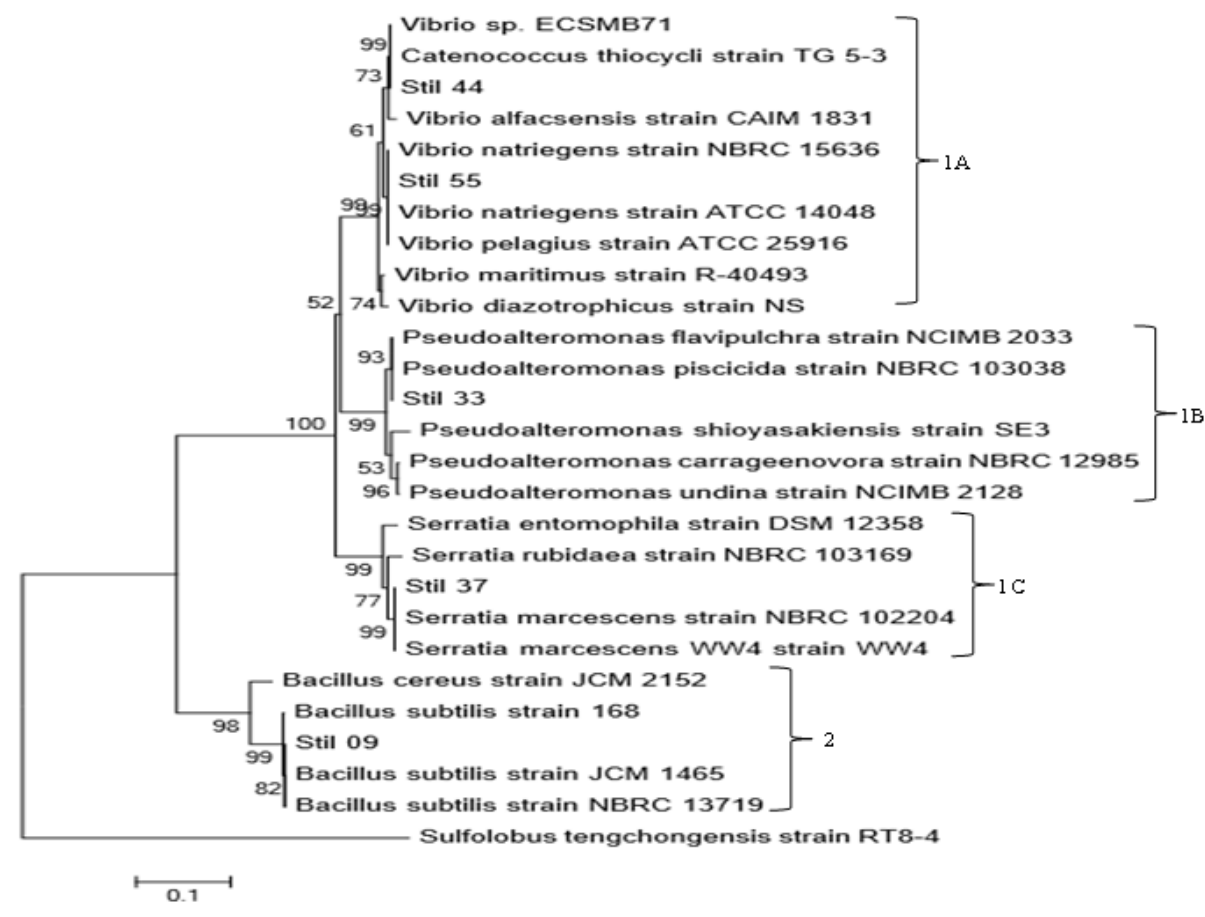

Fig. 3. Phyllogenetic tree of five bacterial isolates isolated from sponge Stylotella sp. compared with reference strains based on 16S rRNA gene sequences using Neighbor-joining method. The scale bar indicates $10 \%$ sequence divergence. Numbers at nodes represent bootstrap values in percentage based on 1000x replications. Clade 1 (Gram negative bacteria): Divided into three sub-clades, i.e., sub-clade 1A. Vibrionaceae (Vibrio, Catenococcus), sub-clade 1B. Pseudoalteromonadaceae (Pseudoalteromonas), sub-clade 1C. Enterobacteriaceae (Serratia); Clade 2 (Gram positive bacteria): Bacillaceae (Bacillus)

As shown in Fig. 3, there were two clades, clade 1 consisted of groups from gram-negative bacteria, while clade 2 of Bacillaceae group. Bacillaceae is grampositive bacteria with bacil cell form, heterotrophic and capable of producing spores in stressed environmental condition. Clade 1 was consisted of three sub-clades, i.e., subs-clade $1 \mathrm{a}, 1 \mathrm{~b}$ and 1c. Sub-clade $1 \mathrm{a}$ was consisted of family Vibrionaceae (genus Vibrio, genus Catenococcus), sub-clade $1 \mathrm{~b}$ of family Pseudoalteromonadaceae (genus Pseudoalteromonas) and sub-clade 1c of family Enterobacteriaceae (genus Serratia). Clade 2 was consisted of family Bacillaceae (genus Bacillus). In addition, Sulfolobus tengchongensis from Archaea strain RT8-4 was selected for out-group.

\section{Discussion}

In this study, bacteria associated with sponge Stylotella sp. producing bioactive compounds were isolated. A total of 138 bacterial isolates with different colony morphology were successfully isolated using five different media (SWC, SCA, NA, MA and ZMA).

High number of bacterial isolates obtained indicated that sponges widely associate with numerous microorganisms. Taylor et al. (2007) reported that 40$60 \%$ sponge tissues with density $10^{9}$ cells $\mathrm{mL}^{-1}$ are symbiotic microorganisms.

The result of this study revealed that SWC media is relatively more effective as isolation media for spongeassociative bacteria than other media (SCA, NA, MA and ZMA), indicated with highest total bacteria $\left(6.6 \times 10^{6}\right.$ $\mathrm{CFU} \mathrm{mL} \mathrm{m}^{-1}$ ) growth in SWC. This was allegedly because complete nutrient composition was provided by SWC media. The media contains glycerol as carbon source and yeast extract as nitrogen source. Sea water composition in SWC media was allegedly responsible for significant increase in the growth of sponge-associated microorganisms. Sea water contains various dissolved 
solid and gas contents, as well as various mineral salts such as calcium, magnesium, sodium, potassium, sulfate, bromide, bicarbonate and chloride. In addition, the salinity of sea water reaches up to $40 \%$, making it optimum for the growth of sea microorganisms (Sharqawy et al., 2010).

During screening stage, 32\% (45 isolates) were found having potential antimicrobial compounds because they showed inhibitory activity toward tested microorganisms (Table 1). Several studies reported that $39(31 \%)$ out of 125 bacteria isolated from sponge Haliclona sp collected from Raja Ampat Island, Indonesia show inhibitory activity toward at least one of tested microorganisms (Tokasaya, 2010). A total of 20 out of 68 isolates isolated from sponge Jaspis sp collected from Raja Ampat Island, Indonesia showed antimicrobial activity against microbial strains (pathogenic and non-pathogenic bacteria and yeast (Abubakar et al., 2011). Other researcher, Santos et al. (2010) have also reported that from 158 bacteria isolated from 9 types of sponge in Brazilian sea, 12 isolates $(9 \%)$ of the total isolates had inhibitory activity toward at least one of the tested microorganisms. A total of 3 out 64 bacterial isolates from sponge Aaptos sp samples from Padang Panjang Island, Indonesia were reported capable of inhibiting the growth of Multi Drugs Resistant (MDR) strains (E. coli and Proteus sp) (Radjasa et al., 2007). In addition, Bharathiraja et al. (2014) reported that 14 bacterial isolates were isolated from sponge Spirastrella inconstans, 5 of them were pigmented and showed inhibitory activity against at least one indicator strain.

Five ethyl acetate extracts from bacterial isolates associated with sponge, which had wide spectrum inhibitory activity to the whole tested microorganisms were toxic, because it had range value of $\mathrm{LC}_{50}$ about 35.89-484.17 $\mu \mathrm{g} \mathrm{mL}^{-1}$. This showed that the extracts had ability, not only as a therapeutic agents to inhibit multiple tested microorganisms, but also as cytotoxic agents. In vitro cytotoxic activity test on $A$. salina was an initial screening to detect any potential anticancer and antitumor in tested extracts, because A. salina performed rapid cell division like cancer cells (Anderson et al., 1991).

Antimicrobial compounds with narrow spectrum activity were found in 29 bacterial isolates (Table 1), as they only were capable of inhibiting one specific tested microorganism. Further development, sponge associated bacteria with narrow spectrum activity were potential to be used in biomedical development as therapeutic agents to treat specific infectious disease after the causative organism is identified. Antimicrobial compounds with narrow spectrum have several advantageous compared with of wide spectrum ones. Species-specific antimicrobial spectrum will not inhibit the growth of normal bacterial flora and reduce the risk of bacterial resistance because it will only inhibit specific target bacteria.

The extracts from five bacterial isolates, i.e., STIL 09, STIL 33, STIL 37, STIL 44 and STIL 55 showed wide spectrum antimicrobial activity, they were able to inhibit many microbial test strains (Table 2 and Fig. 2 ). It indicated that the bacterial extracts contained bioactive compounds. Those isolates were to be the candidates for potential natural products producer for biomedical field development as chemotherapeutic agents to address various disease infections caused by Gram positive or Gram negative bacteria. In this study, isolates STIL 09 and STIL 33 were the candidate for potential chemotherapeutic agents producer against infectious diseases caused by pathogenic bacteria and yeast, while the others for development against infectious diseses caused by pathogenic bacteria.

BSLT using $A$. salina is a simple and fast bioassay method to test bioactivity of extract and has a positive correlation with potential antitumor and anticancer compounds (Anderson et al., 1991). BSLT method is represented with $\mathrm{LC}_{50}$ value (the concentration of tested extract which capable of killing $50 \%$ larvae $A$. salina). Bioactivity of the bacteria associated with sponge Stylotella sp showed that the toxicity was significant in the highest $\mathrm{LC}_{50}$ value of $35.89 \mu \mathrm{g} \mathrm{mL}^{-1}$ (Table 3). The results indicated that the fifth ethyl acetate extracts from bacteria were highly potential to be developed as anticancer agents. Ethyl acetate extracts of bacterial isolates associated with sponge Stylotella sp (STIL 09, STIL 37, STIL 44 and STIL 55). Based on the $\mathrm{LC}_{50}$ value, $\mathrm{LC}_{50}$ value of the bacterial extracts tended to be lower than $\mathrm{LC}_{50}$ of the fraction and hexane extract of Typonium flagelliforme with $\mathrm{LC}_{50}$ value ranged 381.07 to 762.08 $\mu \mathrm{g} \mathrm{mL}^{-1}$ (Sianipar et al., 2013). Toxicity from marine bacteria have also reported by many researchers, such as Utami et al. (2014) said that extracts from marine bacteria associated with sponge Jaspis sp had a toxic effect with $\mathrm{LC}_{50}$ value in the range of 251.18 to $390.50 \mu \mathrm{g} \mathrm{mL} \mathrm{m}^{-1}$ which were performed by three bacterial isolates coded as HAL-74, HAA-01 and HAL-13 isolated from sponge Haliclona sp. at Waigeo Island, Raja Ampat District, Indonesia.

Antioxidant capacity of CUPRAC radical in this study was an equivalent ratio, expressed as Trolox equivalent Antioxidant Capacity (TEAC) (Apak et al., 2008). Antioxidant activity was derived from regression linier standard trolox curve analysis (y = $\left.0.0029 x+0.0275 R^{2}=0.9963\right)$. Out of fifth ethyl acetate extracts of bacterial isolates associated with sponge Stylotella sp, isolate STIL 33 showed the highest 
antioxidant capacity, i.e., $1610.00 \mu \mathrm{mol}$ trolox/g extract, while isolate STIL 37 also showed relative good antioxidant capacity in inhibiting CUPRAC radical with the value of $1202.67 \mu \mathrm{mol}$ trolox/g extract (Table 4). Interestingly, both isolates contained bright pigment color on their morphologies phenotype, in which isolate STIL 33 produced orange color pigment, while isolate STIL 37 produced pink pigment. Isolates with no pigment in this study tended to show lower antioxidant activity. Several pigments have been reported to significantly contribute to the increasing of antioxidant activity. Yellow carotenoid pigment has an important role in photosynthetic aquatic microorganisms and photoprotection against UV radiation in sea water with its high antioxidant activity and capability of inhibiting the formation of cancer cell (Shindo et al., 2008). Acyl-glycol carotenoid acid, the red pigment of Rubritalea squalenifasciens associated with sponge Halicondria okadai, also had antioxidant activity, i.e., capable of inhibiting the formation of radical chain (Thomas et al., 2010). The antioxidant capacity of extract from bacteria associated with sponge Stylotella sp, STIL 09, STIL 33, STIL 37, STIL 44 and STIL 55 were $989.67 \mu \mathrm{mol}$ trolox/g extract, $1610.00 \mu \mathrm{mol}$ trolox/g extract, $1202.67 \mu \mathrm{mol}$ trolox/g extract, $787.33 \mu \mathrm{mol}$ trolox $/ \mathrm{g}$ extract and $445.33 \mu \mathrm{mol}$ trolox/g extract, respectively. Therefore, compared to bacterial isolates from sponges Haliclona and Jaspis sp symbiont which have antioxidant capacity of $649.92 \mu \mathrm{mol}$ trolox/g extract (Utami et al., 2014), ethyl acetate extract of bacterial isolates in this study showed better antioxidant capacity. Bacteria isolated from sponge Stylotella $\mathrm{sp}$ also showed better activity compared to several Chokeberry extracts which also had potential antioxidant and cytotoxic. Aronia prunifolia cultivar had antioxidant activity was $232.30 \mu \mathrm{mol}$ trolox/g extract, cultivar Viking of $A$. Melanocarpa was $206.20 \mu \mathrm{mol}$ trolox/g extract and cultivar Aron of $A$. Melanocarpa was $177.80 \mu \mathrm{mol}$ trolox/g extract (Rugina et al., 2012).

Antioxidant activity from marine bacteria has also reported from many researchers, such as Pereira et al. (2015) reported that bacteria associated with some marine sponge collected from the subtidal marine regions of India had the potential as antioxidant compound. The highest radical reduction activity was found in methanol extract of isolate GUVFCFM-3 with $67.83 \%$ scavenging of DPPH (2,2-diphenyl-2picrylhydrazyl) free radicals and $65.87 \%$ scavenging of superoxide free radicals. Three bacterial isolates associated with sponge Sarcotragus spinolosus and Crambe crambe showed DPPH radical reduction activity more than $40 \%$ with the lowest $\mathrm{IC}_{50}$ values of 851 ppm (Perino et al., 2013). Other marine bacteria such as Bacillus sp. group, isolated from Agatti Island sponge, Lakshadweep archipelago, Maldives, showed potential antioxidant activity against free radicals. $\mathrm{IC}_{50}$ value of the active compound for DPPH activity, $\mathrm{H}_{2} \mathrm{O}_{2}$ scavenging activity, nitric oxide scavenging activity were $15.025,23.730$ and $41.700 \mu \mathrm{g} \mathrm{mL} \mathrm{m}^{-1}$, respectively (Gopi et al., 2014).

Bacterial extracts extracted from bacteria associated with the marine sponge Stylotella sp showed significantly activity in reducing CUPRAC radical. Therefore, all extracts from five bacterial isolates associated with sponge Stylotella sp were potential to be developed as natural antioxidant products from marine bacteria.

\section{Conclusion}

Forty five isolates out of 138 bacteria (32\%) isolated from sponge Stylotella sp produced bioactive compounds with antimicrobial activities. The best antimicrobial activity of ethyl acetate extract was performed by STIL 33. Five potential bacterial extracts, i.e., STIL 09, STIL 33, STIL 37, STIL 44 and STIL 55 showed potential antioxidant and toxicity activities with STIL 33 as the highest antioxidant activity (1610.00 $\mu \mathrm{mol}$ trolox/g extract) and STIL 37 showed the strongest toxicity $\left(\mathrm{LC}_{50}=35.89 \mu \mathrm{g} \mathrm{mL}^{-1}\right)$. Those bacterial extract can be developed as antimicrobial and antioxidant agents.

\section{Acknowledgement}

This study was partially funded by "Insentif Riset SINAS", The Ministry of Research, Technology and Higher Education, The Republic of Indonesia 2015 to ATW. Therefore, We are grateful for this funding and support of this research.

\section{Funding Information}

This work was partially supproted by "Insentif Riset SINAS", The Ministry of Research, Technology and Higher Education, Republic of Indonesia 2015.

\section{Author's Contributions}

Daning Yoghiapiscessa: Took part in all experiment process as well as data analysis and manuscript preparation.

Irmanida Batubara: Involved in study design, result verification and scientific discussion.

Aris Tri Wahyudi: Coordinated the study, integrated all data and involved in manuscript writing. 


\section{Ethics}

This article is original and contains unpublished material. The corresponding author confirms that all of the other authors have read and approved the manuscript and no ethical issues involved.

\section{References}

Abubakar, H., A.T. Wahyudi and M. Yuhana, 2011. Skrining bakteri yang berasosiasi dengan spons Jaspis sp. sebagai penghasil senyawa antimikroba. Ilmu Kelautan, 16: 35-40.

Anderson, J.E., C.M. Goetz., J.L. McLaughlin and M. Suffness, 1991. A blind comparison of simple bench-top bioassay and human tumour cell cytotoxicities as antitumor prescreens. Phytochem. Anal, 2: 107-111. DOI: 10.1002/pca.2800020303

Apak, R., K. Guclu, M. Ozyurek and S.E. Celik, 2008. Mechanism of antioxidant capacity assays and the Cupric ion Reducing Antioxidant Capacity (CUPRAC) assay. Microchim. Acta, 160: 413-419. DOI: $10.1007 / \mathrm{s} 00604-007-0777-0$

Bharathiraja, S., R. Rajasekaran and J. Suriya, 2014. Antibacterial activity of marine bacteria isolated from sponge Spirastrella inconstans. J. Chem. Pharm. Res., 6: 395-398.

Gopi, M., N.B. Dhayanithi, K.N. Devi and T.T.A. Kumar, 2014. Marine natural product, Pyrrolo[1,2a]pyrazine-1,4-dione, hexahydro- (C7H10N2O2) of antioxidant properties from Bacillus species at Lakshadweep archipelago. J. Coast. Life Med., 2: 632-637.

DOI: $10.12980 /$ JCLM.2.201414J40

Jeganathan, P., K.M. Rajasekaran, A.N.K. Devi and S. Karuppusamy, 2013. Antimicrobial activity and characterization of marine bacteria. Ind. J. Pharm. Biol. Res., 1: 38-44.

Marchesi, J.R., T. Sato, A.J. Weightman, A.T. Martin and J.C. Fry et al., 1998. Design and evaluation of useful bacterium-specific PCR primers that amplify genes coding for bacterial $16 \mathrm{~S}$ rRNA. Applied Environ. Microbiol., 64: 795-799. PMID: 9464425

Mehbub, M.F., J. Lei, C. Franco and W. Zhang, 2014. Marine sponge derived natural products between 2001 and 2010: trends and opportunities for discovery of bioactives. Mar. Drugs, 12: 4539-4577. DOI: $10.3390 / \mathrm{md} 12084539$

Meyer, B.N., R.N. Ferrigini., L.B. Jacobsen, D.E. Nicholas and J.L. Laughin, 1982. Brine shrimp: A convenient general bioassay for active plant constituents. Planta Med., 45: 31-35. DOI: $10.1055 / \mathrm{s}-2007-971236$
Muller, W.E.G., V.A. Grebenjuk, N.L. Thakur, A.N. Thakur and R. Batel et al., 2004. Oxygencontrolled bacterial growth in the spons Suberites domuncula: Toward a molecular understanding of the symbiotic relationships between spons and bacteria. J. Applied Environ. Microbiol., 70: 2332-2341.

Nazim, K., S.K. Sherwani, M.U. Khan, R. Kausar and G. Rizvi, 2014. Antibacterial activity of marine sponge collected from Sunhari Beach. FUUAST. J. Biol., 4: 233-236.

Penesyan, A., Z.M. Jones, C. Holmstrom, S. Kjelleberg and S. Egan, 2009. Antimicrobial activity observed among cultured marine epiphytic bacteria reflects their potential as asource of new drugs. FEMS. Microbiol. Ecol., 69: 113-124. DOI: $10.1111 / \mathrm{j} .1574-6941.2009 .00688$

Pereira, S.V., P. Parvatkar and I.J. Furtado, 2015. Evaluation of antioxidant producing potential of halophilic bacterial bionts from marine invertebrates. Ind. J. Pharm. Sci., 77: 183-189. DOI: $10.4103 / 0250-474 X .156572$

Perino, E., A. Horta, R. Manconi, R. Pronzato and R. Pedrosa, 2013. Antioxidant activities in Sarcotragus spinolosus and Crambe crambe (porifera, demospongiae) associated bacteria. Rapp. Comm. Int. Mer Medit. DOI: 10.1016/j.copbio.2013.05.119

Radjasa, O.K., D.S. Kencana, A. Sabdono, R.A. Hutagalung and E.S. Lestari, 2007. Antibacterial activity of marine bacteria associated with sponge Aaptos sp. against Multi Drugs Resistant (MDR) strains. J. Mate. Dan Sains, 12: 4147-152.

Rugina, D., Z. Sconta, L. Leopold, A. Pintea and A. Bunea et al., 2012. Antioxidant activities of chokeberry extracts and the cytotoxic action of their anthocyanin fraction on HeLa human cervical tumor cells. J. Med. Food, 15: 700-706.

DOI: $10.1089 / \mathrm{jmf} .2011 .0246$

Santos, O.C.S., P.V.M.L. Pontes, J.F.M. Santos, G. Muricy and M. Giambiagi-deMarval et al., 2010. Isolation, characterization and phylogeny of sponge-associated bacteria with antimicrobial activities from Brazil. J. Res. Microbiol., 161: 604-612. DOI: 10.1016/j.resmic.2010.05.013

Sharqawy, M.H., J.H. Lienhard and S.M. Zubair, 2010. Thermophysical properties of seawater: A review of existing correlations and data. Desalinat. Water Treatment, 16: 354-380. DOI: $10.5004 /$ dwt.2010.1079

Shindo, K., E. Asagi, A. Sano, E. Hotta and N. Minemura et al., 2008. Diapolycopenedioic acid xylosyl esters a, b and c, novel antioxidative glycoc30-carotenoic acids produced by a new marine bacterium Rubritalea squalenifaciens. J. Antibiot., 61:185-191. PMID: 18503197 
Sianipar, N.F., W. Maarisit and A. Valencia, 2013. Toxic activities of hexane extract and column chromatography fraction of rodent tuber plant (Typhonium flagelliforme Lodd) on Artemia salina. Indones. J. Agric. Sci., 14: 1-6.

Taylor, M.W., R. Radax, D. Steger and M. Wagner, 2007. Spons-associated microorganisms: Evolution, ecology and biotechnological potential. J. Microbiol. Mol. Biol. Rev., 71: 295-347.

DOI: 10.1128/MMBR.00040-06

Thomas, T.R.A., D.P. Kavlekar and P.A. Lokabharathi, 2010. Marine drugs from sponge-microbe association-a review. Mar. Drugs, 8: 1417-1468. DOI: $10.3390 / \mathrm{md} 8041417$
Tokasaya, P., 2010. Spons-associated bacteria producing antimicrobial compounds and their genetic diversity analysis. Unpublished thesis in partial fulfillment of the requirements for the degree of undergraduate of Microbiology, Bogor Agricultural University, Bogor, West Java, Indonesia

Utami, A.W.A., A.T. Wahyudi and I. Batubara, 2014. Toxicity, anticancer and antioxidant activity of extracts from marine bacteria associated with sponge Jaspis sp. Int. J. Pharma. Bio. Sci., 5: 917-923. 